Review

\title{
FACTORS AFFECTING THE RISK OF FREE FLAP FAILURE IN MICROVASCULAR SURGERY
}

\author{
Jevgeṇijs Stepanovs $s^{1,3 \#}$, Agnese Ozolinaa ${ }^{2,3}$, Vita Rovīte ${ }^{4}$, Biruta Mamaja ${ }^{1,3}$, \\ and Indulis Vanags 2,3 \\ ${ }^{1}$ Rīga Eastern Clinical University Hospital, Hipokrāta iela 2, Rīga, LV-1038, LATVIA; jevgenijs.stepanovs@aslimnica.Iv \\ 2 Pauls Stradiṇš Clinical University Hospital, Pilsoṇu iela 13, Rīga, LV-1002, LATVIA \\ ${ }^{3}$ Department of Anaesthesiology and Reanimatology, Rīga Stradiṇš University, Dzirciema iela 16, Rīga, LV-1007, LATVIA \\ ${ }^{4}$ Latvian Biomedical Research and Study Centre, Rātsupītes iela 1, Rīga, LV-1067, LATVIA \\ \# Corresponding author
}

Communicated by Rafails Rozentāls

\begin{abstract}
Microvascular free flap surgery, has become an important part of reconstructive surgery during the last decades, as it allows closure of various tissue defects and recovery of organs function. Despite surgical progress resulting in high rates of transferred tissue survival, the risk of pedicle vessels thrombosis still remains a significant problem. A total of 108 articles from Pubmed and Science Direct databases published in 2005-2015 were analysed. This review of the literature assessed the influence of patient-dependent risk factors and different perioperative management strategies on development of microvascular free flap thrombosis. Sufficient evidence for risk associated with hypercoagulation, advanced age and certain comorbidities was identified. Presently, rotational thromboelastometry allows early hypercoagulability detection, significantly changing further patient management. Identification of flap thrombosis promoting surgery-related aspects is also essential in preoperative settings. Choice of anaesthesia and postoperative analgesia, administration of different types and amounts of fluids, blood products and vasoactive agents, temperature control are no less important in perioperative anaesthesiological management. More attention should be focused on timely preoperative evaluation of patient-dependent risk factors, which can influence anaesthesiological and surgical tactics during and after microvascular free flap surgery. Perioperative anaesthesiological management strategy continues to be controversial and therefore it should be performed based on thrombotic risk assessment and patient individual needs, thus improving flap survival rates and surgical outcome.
\end{abstract}

Key words: reconstructive surgery, free tissue transfer, free flap failure, anaesthesia.

\section{INTRODUCTION}

The aim of reconstructive surgery is the restoration of shape and function of the tissue lost due to trauma, oncological surgery, congenital defect, burns and infection. Free flap surgery has become a fundamental part of reconstructive surgery; the technique involves separation of the tissue flap from its original vascular supply and microvascular reanastomosis of the pedicle artery and vein at a recipient site. The first free tissue transfer was performed in 1972, using a free omental flap for scalp defect reconstruction (McLean and Buncke, 1972). Early flap failure rates reached 40 to 50 per cent. Later the techniques for microvascular tissue transfer steadily evolved, resulting in higher success rates (Wei et $a l$., 2002). Since the introduction of free tissue transfer, advances have resulted in success rates of 90 to 99 per cent among experienced surgeons (Gardiner and Nanchahal, 2010; Kakarala et al., 2012; Brinkman et al., 2013). Despite this progress, vascular thrombosis still remains one of the major postoperative complications after free flap microvascular surgery (Godina, 1979). It is associated with higher morbidity, potential flap loss, higher costs, and increased length of hospital stay. Total flap failure and even partial loss may have devastating consequences, although they are rare (Fig. 1). In those cases, not only the reconstruction has failed, but then a donor site scar is present - two holes instead of one.

A number of modifiable factors in the perioperative period have the potential influence to free tissue transfer outcomes. Long duration of the surgery, with high surgical-anaesthetic risk, and comorbidities may affect success of the technique (e.g., hypercoagulability, diabetes mellitus, poor nutritional status, cardiovascular disease, peripheral vascular disease, collagen diseases). Moreover, anaesthesia may be an important and determining factor due to its role in maintaining 

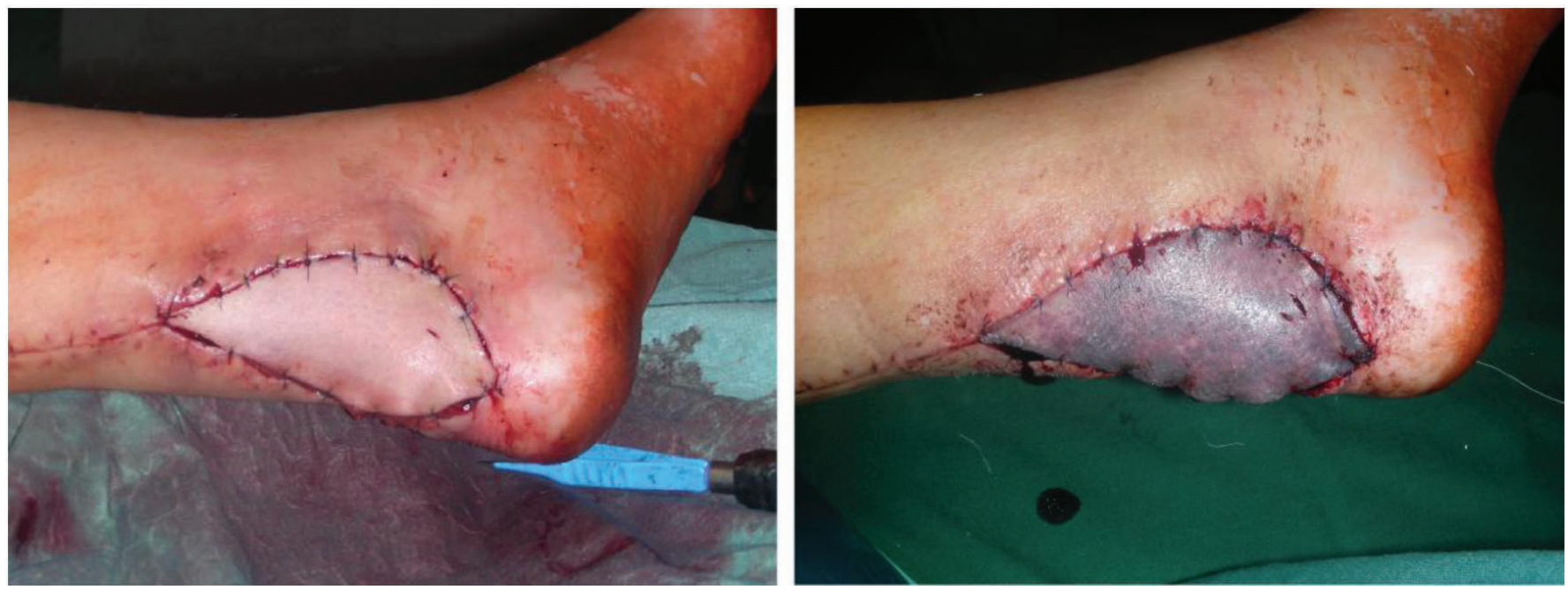

Fig. 1. Tissue defect closed with $a$. radialis free flap before and after microvascular flap thrombosis.

haemodynamic stability and regional blood flow. Also, blood flow in the flap can be influenced by regional anaesthesia, changes in blood volume, and vasoactive drugs (Sigurdsson and Thomson, 1995; Adams and Charlton, 2003).

The aim of this review was to collect literature data from the last decade, which demonstrates the role of preoperative patient-dependent risk factors and diversity of perioperative anaesthesiological management strategies affecting the risk of free flap failure in microvascular surgery.

Surgical phases and direct causes of free flap thrombosis. The majority of thrombosis cases occur within 2-3 postoperative days (Chang et al., 2013); venous thrombosis is more common than arterial occlusion. The main surgical phases and causes of thrombosis are common for all microvascular free flap transfer surgery cases. The basic steps of flap transfer are:

- Flap separation and clamping of blood vessels;

- Cessation of blood flow causing primary ischemia and initiating anaerobic intracellular metabolism (depending on surgical time it lasts 60-90 $\mathrm{min}$ );

- Reperfusion after the anastomoses are completed and the clamps are released. Secondary ischemia can occur following attachment, after a free flap has been transferred and reperfused. Risk of secondary ischemia can be minimised by optimal anaesthetic technique and appropriate fluid therapy (Quinlan and Lodi, 2009).

Flap vascular thrombosis is one of the major perioperative complications of microvascular surgery. Numerous factors may contribute to free flap failure, but direct causes are (Adams \& Charlton, 2003):

- Vasospasm for arterial thrombosis;

- Impairment of venous drainage due to vasospasm and mechanical compression (e.g., dressings, positioning) for venous thrombosis;
- Progressive flap oedema caused by excessive use of crystalloids, excessive hemodilution, prolonged ischemia, histamine release (e.g., anaesthetics, antibiotics), flap excessive manipulation.

- Generalised vasoconstriction: hypovolemia, hypothermia, pain, respiratory alkalosis (e.g., decreased cardiac output).

- Hypotension: hypovolemia, myocardium depressor drugs (e.g., anaesthetics, $\mathrm{Ca}^{2+}$ channel blockers), vasodilation, heart failure (e.g., ischemia, volume overload, acidosis).

- Prolonged ischemia of the flap.

\section{METHODOLOGY OF THE REVIEW}

We performed a review of current literature in order to identify factors negatively influencing microvascular free flap surgery results, divided into three groups: preoperatively identifiable patient dependent risk factors, surgery dependent risk factors, and perioperative anaesthesiological management strategies. PubMed and Science Direct databases were used. The search was performed using the following algorithm and key terms: (preoperative assessment) or (perioperative management) or (temperature) or (anaesthesia) or (fluids) or (vasopressors) or (vasodilators) or (anticoagulants) and (free flap failure) or (free flap reexploration) or (free flap thrombosis). A total of 108 English language articles published in 2005-2015 were selected and analysed.

\section{PREOPERATIVE PATIENT-DEPENDENT RISK FAC- TORS}

While there have been long-lasting discussions during the last decade about different aspects of patient perioperative management, much less effort has been focused on preoperative identification of potentially high-risk thrombosis pa- 
tients. Numerous patient-dependent risk factors can be established preoperatively, which negatively influence free tissue transfer outcome.

Hypercoagulatation. Flap loss most often occurs because of thrombosis of the microvascular pedicle, which is secondary to technical factors, such as intima damage, vessel kinking, and technical errors regarding the anastomosis (Stepanovs et al., 2015). However, even despite appropriate surgical technique and follow-up, flap failures can be encountered due to systemic influences - acquired or hereditary coagulation disorders like a posttraumatic hypercoagulable state or resistance to activated protein $\mathrm{C}$ (Yu et al., 2009; Wang et al., 2012). Hypercoagulability is a propensity for inappropriate or pathological thrombus formation.
Approximately $5-10 \%$ of the population is estimated to have a hypercoagulable condition, which frequently is unrecognised or not detectable by routine tests (Rosendaal, 1999; Kitchens, 2008). Some authors have assessed the use of rotational thromboelastometry (RTE) for hypercoagulability detection in free flap surgery (Kolbenschlag et al., 2014; Wikner et al., 2015) (Fig. 2). RTE analysis is based on an in vitro clotting process. It generates a real-time image of in vitro clot formation, demonstrating the interaction between plasmatic components of coagulation and cellular elements. RTE has been used in clinical settings to detect hypo- or hyper-coagulability, fibrinolysis and clot strength, mostly for haemorrhagic trauma or bleeding cardiac surgery patients. In a recent systematic review, RTE has been shown as an effective tool to evaluate coagulation distur-
Institute

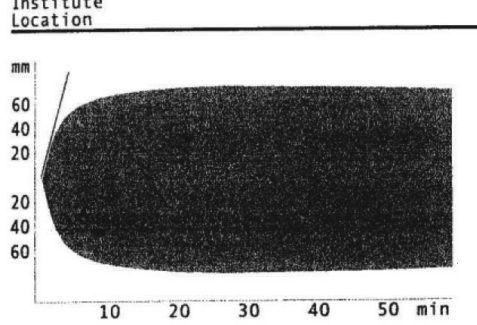

20 nod.
ROTEM Analyser. Tem Innovations

\begin{tabular}{|c|c|c|c|c|c|c|c|}
\hline 1 & $\begin{array}{l}\text { EXTEM } \\
1:\end{array}$ & & \multicolumn{5}{|c|}{$2: 080928$} \\
\hline RT: & $01: 00: 25$ & & ST: & $2014-11-20$ & $T 1$ & $45: 46$ & \\
\hline CT & : & 62 & $s$ & 38 & - & 79] & \\
\hline CFT & : & 50 & $\mathbf{S}$ & 34 & - & 159] & \\
\hline$\alpha$ & : & 80 & $\circ$ & 63 & - & 83] & \\
\hline A10 & : & 70 & $\mathrm{~mm}$ & 43 & - & 65] & $\Delta$ \\
\hline $\mathrm{A} 20$ & : & 76 & $\mathrm{~mm}$ & 50 & - & $71]$ & $\Delta$ \\
\hline MCF & : & 77 & $\mathrm{~mm}$ & 50 & - & 72] & $\Delta$ \\
\hline ML & : * & 5 & $\%$ & 0 & - & 15] & \\
\hline
\end{tabular}

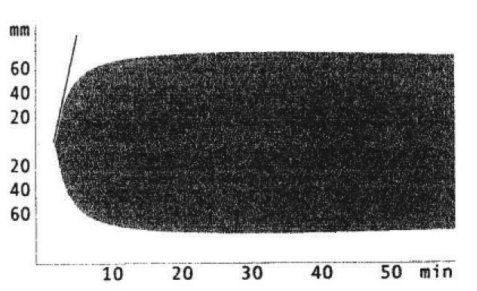

20nod.

\begin{tabular}{|c|c|c|c|c|c|c|}
\hline 2 & $\begin{array}{l}\text { INTEM } \\
1:\end{array}$ & & \multicolumn{4}{|c|}{ 2:080928 } \\
\hline RT: & $01: 00: 28$ & & ST: & $2014-11-20$ & $T 10: 47: 18$ & \\
\hline $\mathrm{CT}$ & : & 163 & $\mathrm{~s}$ & [ 100 & - 240] & \\
\hline CFT & : & 42 & s & 30 & - 110$]$ & \\
\hline$\alpha$ & : & 81 & $\circ$ & 70 & $83]$ & \\
\hline A10 & : & 70 & $\mathrm{~mm}$ & 44 & $66]$ & $\Delta$ \\
\hline A 20 & : & 75 & $\mathrm{~mm}$ & 50 & 71] & $\Delta$ \\
\hline MCF & : & 75 & $\mathrm{~mm}$ & 50 & 72] & $\Delta$ \\
\hline$M L$ & : * & 4 & $\%$ & 0 & 15] & \\
\hline
\end{tabular}

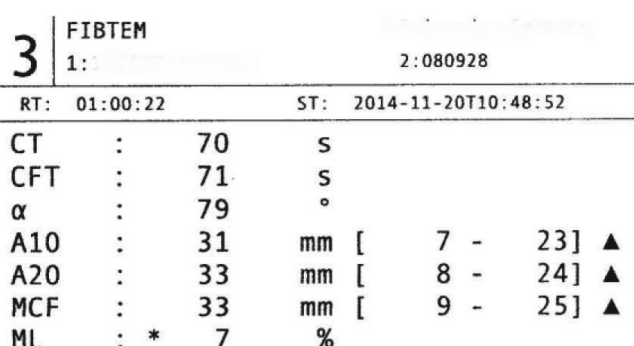
20 nod.

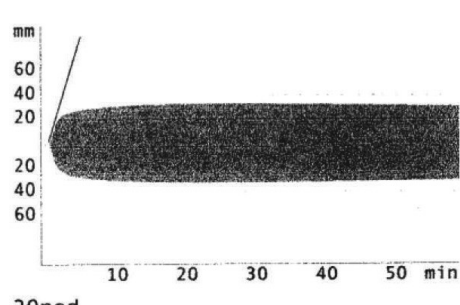

\begin{tabular}{lrrrr}
\multicolumn{2}{l}{$\begin{array}{l}\text { APTEM } \\
\text { 1: }\end{array}$} & & \multicolumn{2}{c}{$2: 080928$} \\
\hline \multicolumn{2}{l}{ RT: } & $01: 00: 23$ & & ST: $2014-11-20 \mathrm{~T} 10: 50: 15$ \\
\hline CT & $:$ & 61 & S \\
CFT & $:$ & 54 & S \\
$\alpha$ & $:$ & 79 & $\circ$ \\
A10 & $:$ & 69 & $\mathrm{~mm}$ \\
A20 & $:$ & 75 & $\mathrm{~mm}$ \\
MCF & $:$ & 76 & $\mathrm{~mm}$ \\
ML & $:$ & $*$ & 4 & $\%$
\end{tabular}

$2014-11-20 T 12: 04: 08$

1:PatID/QC-lot 2:SampID/QC-exp

Fig. 2. Rotational thromboelastometry (RTE) test in a patient with hypercoagulability and thrombotic flap loss. 
bances in septic conditions where the clotting process often is enhanced despite the presence of a low platelet count (Müller et al., 2014). In patients undergoing free flap transfer surgery, Kolbenschlag et al. found RTE as a useful tool for screening coagulation balance and prediction of thrombotic complication (Fig. 2). However, Wikner et al. could not confirm these results and recommended RTE only for assessment of the anticoagulation needs of individual patients undergoing free flap surgery.

In some cases thrombosis may develop only in the presence of an additional factor like oral contraception, another surgery, or cancer (De Stefano et al., 1999; Olsson et al., 2001; Vandenbroucke et al., 2001). Genetic mutations, such as factor V Leiden (Davison et al., 2009; Khansa et al., 2011), factor VIII levels (Höijer \& Olsson, 2006), AT III mutations, decreased protein C (Handschel et al., 2013) and $\mathrm{S}$ levels, and hyperhomocisteinemia (Labow et al., 2007) have been demonstrated as possible reasons of free flap failure in various reconstruction types. Hereditary or acquired posttraumatic coagulation disorders can lead not only to more frequent flap thrombosis, but also to worse results in case of reexploration. Free tissue transfer is still possible, but the success rate is only 80 per cent, as demonstrated by a study that investigated a series of 58 flaps (Wang et al., 2012). Consequently, special attention should be paid to assessment of thrombophilia, and detailed preoperative evaluation is crucial. Some institutions recommend to change the surgery plan and to close tissue defect with a pedicle flap instead of free flap due to higher risk of thrombosis (Sezgin et al., 2012).

Advanced age and comorbidities. Chronological age alone is considered not to be a contraindication for surgery or a risk factor for postoperative morbidity and flap failure (Ozkan et al., 2005; Wong et al., 2014). Comorbidities, including chronic obstructive pulmonary disease (Fischer et al., 2013), complications of diabetes (Lee et al., 2014; Scalia et al., 2007), smoking history (Brands et al., 2010; Chang, 2006), high American Society of Anesthesiologists (ASA) status (Coskunfirat et al. 2005), and malnutrition (Shum et al., 2014), have more negative influence to flap failure. Smoking should be stopped as much as possible (Kuri et al. 2005). Advanced age often goes together with chronic cardiac failure, aortic valve stenosis, and decreased systolic function. This is well known, since low cardiac index cannot provide flap perfusion pressure and left ventricular failure guarantees loss of transferred tissue (Adams and Charlton, 2003). Perhaps patients with significant cardiac disease should undergo less ambitious surgery, although aesthetically less satisfactory. Peripheral vascular disease was found to be a statistically significant risk factor for flap thrombosis in breast reconstruction surgery (Masoomi et al., 2014). Similar results were found by Lee et al. in diabetic patients with tissue defects of the lower extremities, and atherosclerotic calcifications were confirmed as risk factors for flap survival (Lee et al., 2014). No atherosclerotic calcifications were seen in the complete healing group, although they were found in 12 patients in the com- plication group, and this difference was significant (Lee et al., 2014).

In contrast, in 10-years follow-up of cases, advanced age was identified as the only factor for increased risk of subsequent flap loss in cases revised due to thrombosis in patients undergoing lower extremity reconstruction surgery. Other factors such as cardiovascular disease, diabetes mellitus, body mass index and history of smoking were not associated with increased risk of flap thrombosis (Wettstein et al., 2008).

Preoperative anaemia. Patients undergoing microvascular reconstruction are often anaemic from a combination of iatrogenic haemodilution and acute blood loss. Preoperative anaemia with haematocrit (Hct) level less than $30 \%$ and haemoglobin $(\mathrm{Hb})$ less than $10 \mathrm{~g} / \mathrm{dl}$ can significantly impact free flap morbidity (Hill et al., 2012). However, some studies have not confirmed these results (Mlodinow et al. 2013). Haemoglobin and haematocrit levels should be optimised before surgery $(\mathrm{Hb}>10 \mathrm{~g} / \mathrm{dl}$, Hct $>30$ per cent) (Clark et al., 2007).

\section{PREOPERATIVE SURGERY DEPENDENT RISK FAC- TORS}

Data from the literature suggest that duration of surgical reconstruction as well as specific defect localisation and tissue flap type may significantly affect survival of free flap. These aspects should be considered by the surgeon before intervention, in order to offer an optimal plan for tissue defect closing.

Prolonged operation time. Duration of surgery exceeding eight hours is likely to occur in head and neck free flap surgery (Wolff et al., 2008; Al-Dam et al., 2014). Longer time spent in the operation theatre is a significant prognostic factor for overall medical complications in free flap surgery (Rosenberg et al., 2009). Additionally, in a study including 639 patients undergoing 778 flaps over a four-year study period, operative time was identified as an independent risk factor for free flap failure. After adjusting for other factors, those whose operative time was equal to or greater than the $75^{\text {th }}$ percentile $(625.5 \mathrm{~min})$ were twice as likely to experience flap failure (Wong et al., 2014).

Defect localisation and type of reconstruction. Additional risk factors associated with tissue defect localisation and type of flap (Table 1) are identified in the analysed articles. Also, some general factors like comorbidities have positive predictive value only in specific types of surgery.

The most common cause of thrombosis is technical error or local factor, such as intima trauma, vessel kinking, and technical anastomotic problems. Nevertheless, preoperative identification of high thrombotic risk patient- and surgeryrelated risks further can affect perioperative anaesthesiological management strategy. 
TISSUE DEFECT-RELATED RISK FACTORS FOR FREE-FLAP THROMBOSIS

\begin{tabular}{|c|c|}
\hline $\begin{array}{c}\text { Region of tissue } \\
\text { defect }\end{array}$ & Related risk factors \\
\hline Head, neck & $\begin{array}{l}\text { History of radical concurrent } \\
\text { chemoradiotherapy (Yoshimoto, Kawabata, Mitani, } \\
\text { 2010) } \\
\text { Proximal defect localisation (Gerressen et al., 2013) } \\
\text { Acute malnutrition (Shum et al., 2014) }\end{array}$ \\
\hline Breast & $\begin{array}{l}\text { Reconstruction with free superficial inferior } \\
\text { epigastric artery (SIEA) flap (Masoomi et al., 2014) }\end{array}$ \\
\hline Lower extremity & $\begin{array}{l}\text { History of angioplasties in the extremity (Oh et al., } \\
2013 \text { ) } \\
\text { Using immunosuppressive agents after kidney trans- } \\
\text { plant in diabetic patients (Oh et al., 2013) } \\
\text { Tissue defect localisation in the distal tibia region } \\
\text { (Fischer } \text { et al., 2013) } \\
\text { Reconstruction with rectus abdominis flap (Fischer et } \\
\text { al., 2013) }\end{array}$ \\
\hline
\end{tabular}

\section{PERIOPERATIVE ANAESTHESIOLOGICAL MAN-} AGEMENT STRATEGIES

Basic principles of anaesthesia for free flap transfer should be maintenance of low viscosity, vasodilatation and good perfusion pressure.

Perioperative anticoagulation. Data regarding anticoagulation regimens remain inconclusive. Clinical studies comparing various anticoagulation regimens have shown equivalent reduction in the incidence of complications, including anastomotic thrombosis and flap loss (Chien et al., 2005; Lighthall et al., 2013). In a large study on prospective free tissue transfer, low-molecular-weight heparin (LMWH) used after the surgery demonstrated similar effectiveness with subcutaneous unfractioned heparin in prevention of postoperative flap thrombosis (Khouri et al., 1998). A retrospective review comparing LMWH and aspirin administered after surgery indicated similar rates of complications, including haematoma formation and free flap failure, when compared to other anticoagulation regimens (Ashjian et al., 2007). Small doses of unfractioned heparin also does not appear to increase the risk of postoperative haematoma and haemorrhage (Nahabedian et al., 2008). Interestingly, intraoperative systemic heparin was found to have no effect on the incidence of microvascular thrombosis (Chen et al., 2008). In contrast, postoperative use of subcutaneous unfractioned heparin reduces the incidence of postoperative flap thrombosis significantly. In summary, various anticoagulation regimens tend to show equivalent reduction in the incidence of complications. Aspirin orally and heparin subcutaneously alone or in combination can be recommended for postoperative antithrombotic management.

Anaesthesia and choice of anaesthetics. Most authors suggest balanced general anaesthesia as an optimal method during prolonged free flap procedures (Hagau and Longrois, 2009). Earlier publications suggest that isoflurane has the advantage over other inhalation agents and propofol due to producing vasodilation with minimal cardiac depression. However, recent studies offer sevoflurane as a better agent because of its beneficial effects on microcirculation, reducing plasma leakage into interstitial space, therefore reducing flap oedema (Bruegger et al., 2002). Some papers suggest that it may have a protective effect on endothelial cells against ischemia-reperfusion injury (Lucchinetti et al., 2007; Annecke et al., 2010). Regarding regional anaesthesia methods, older studies demonstrated free flap "steal phenomena" due to inability to dilate transplanted vessels in the sympathetically denervated recipient zone after regional block. In contrast, studies conducted in the last decade support the idea of supplemental regional anaesthesia for digit replantation and lower extremity free flaps (Kurt et al., 2005; Su et al., 2005; Bozkurt et al., 2010; Cayci et al., 2010).

Perioperative analgesia. Regional anaesthesia may be beneficial, considering necessity to ensure perioperative analgesia, especially for the pain site. Conflicting data have been reported about epidural analgesia. After epidural blockade, the "steal phenomena" has been revealed as well. As shown by authors in an older report, microcirculatory blood flow was markedly decreased in lower extremity free flaps by redistributing it away from the flap to normal intact tissues, as measured by multichannel laser Doppler flowmetry after epidural blockade (Erni et al., 1999). Some authors argue that reduction of microcirculatory blood flow can be explained by effect of the centroaxial blockade on cardiac output and mean arterial pressure. However, recent papers suggest that use of epidural analgesia should be beneficial. Concerning peripheral nerve blocks, several clinical studies have demonstrated that peripheral nerve blocks reduce vasospasm and improve perfusion of replanted or revascularised digits. Nonsteroidal anti-inflammatory drugs should be avoided, because of the risk of perioperative bleeding and hematoma formation. On the other hand, ketorolac reduces thrombotic complications in lower extremity free flaps (Lee et $a l .$, 2012).

Fluid administration. Appropriate blood flow and oxygen delivery to the free flap have to be ensured to reduce perioperative complications. Hyperdynamic circulation with high cardiac output, pulse pressure, and peripheral vasodilation is required to maintain perfusion pressure in transplanted flaps. Traditionally, hypervolemic haemodilution has been used during anaesthesia for this type of surgery. Because free flaps are subjected to interstitial oedema, excessive fluid administration can be deleterious (Shetty et al., 2009). Many studies have demonstrated correlation between high volumes of perioperative crystalloid infusions and flap as well as overall complications (Patel et al., 2010; Chappell et al., 2008). In a retrospective study of 104 free transverse rectus abdominis myocutaneous flaps, patients with thrombosis of the flap anastomosis received significantly higher fluid volumes during the surgery (Booi, 2011). Moreover, a review of 354 breast reconstructions showed that crystalloid infusion rate is a significant predictor of complications (Zhong et al., 2011). Only a few studies have 
examined the role of colloids to replace intraoperative blood loss (Arellano et al., 2005), without giving any negative information of modern hydroxyethyl starches. Therefore, patients should receive limited amounts of crystalloids only for basic physiological needs to avoid causing flap oedema. Synthetic colloids should be administered to replace intraoperative blood loss, and blood products given to maintain haematocrit (Karakida et al., 2010). The ideal rate of crystalloid infusions is 3.5 to $6.0 \mathrm{ml} / \mathrm{kg}$ per hour in a 24 hour perioperative period (Motakef et al., 2015). In contrast with older studies that suggested to use dextran due to its rheological properties, a review of 1351 free flaps showed that dextran in high-risk oncological patients significantly increased the rate of flap failure without showing any influence on flap survival, compared to no antithrombotic therapy (Riva et al., 2012). Benefit of dextran infusions in terms of flap survival has not been clinically demonstrated yet (Pohlenz et al., 2007). Furthermore, dextran administration is associated with higher incidence of systemic complications (Disa et al., 2003).

Transfusion of blood products. Preoperative anaemia is associated with an increased length of hospital stay and is a significant predictor of flap failure and thrombosis. On the other hand, perioperative transfusions have negative influence on patient morbidity, as shown in patients undergoing cardiac surgery (Zellans et al., 2014) and reconstructive free flap surgery (Szakmany et al., 2006).

Blood loss can be remarkable during extensive and long microvascular surgery. The loss can be very slow, but long-lasting, and therefore assessment can be false and the real value of haemoglobin can be revealed only in later postoperative days. Red blood cells transfusions should be performed to maintain $\mathrm{Hb}$ and $\mathrm{Hct}$ at appropriate levels for adequate perfusion and tissue oxygen delivery. However, transfusions have to be performed with caution and a more restrictive transfusion strategy should be applied (KozekLangenecker et al., 2013), considering association between amount of intraoperative blood products transfused and higher rates of complications, requirements of postoperative transfusions and reoperations (Kim et al., 2014). In addition, perioperative transfusions were found to have negative influence on morbidity and mortality in free flap reconstruction surgery, including cancer recurrence (Kao et al., 2010) and promotion of wound infections (Liu et al., 2007)' due to their immunomodulatory effect (Vamvakas and Blajchman, 2007). It is recommended to use a restrictive strategy, and reserve transfusions for clinically symptomatic patients or those with haemoglobin level less than $7 \mathrm{~g} / \mathrm{dl}$.

Vasoactive drugs. Although vasodilators are widely used for topical application due to their favourable effect on flap flow, usage of vasopressors is more conservative to balance the risk of vasoconstriction and the potential benefit of increased mean arterial pressure, which subsequently improves perfusion pressure across the free flap. Administration of vasopressors before division of the free flap may affect the size of the perforator and thus the technical difficulty of the dissection. Unlike as in older studies, in recent studies show that administration of vasopressors following flap division does not impact flap outcomes (Chen et al., 2010; Monroe et al., 2010; 2011). Prospective studies comparing effect of epinephrine, norepinephrine, dobutamine, and dopexamine demonstrated that both dobutamine and norepinephrine improved blood flow in free flap skin, with norepinephrine yielding the greatest improvement (Eley et al., 2012; 2013). After division of the flap, if a vasopressor is needed, it should be tailored for maintaining blood pressure and flap flow, despite widespread prejudice and information given in older studies (Louer et al., 2013), helping to avoid excessive fluid administration and interstitial oedema. Preferable agents are norepinephrine and dobutamine. In contrast, dopexamine and epinephrine can decrease flap flow. Beta-blockers should be avoided as they can cause relative vasoconstriction in peripheral tissues.

Temperature management. Conflicting data exists regarding intraoperative temperature control. Some studies (Thomson et al., 2009; Liu et al., 2011; ) report correlation of mild hypothermia with lower rates of flap thrombosis. However, the majority of reports on humans show that hypothermia is associated with perioperative complications. A retrospective study of 156 free flaps demonstrated correlation between intraoperative hypothermia (average core temperature, $<35.0{ }^{\circ} \mathrm{C}$; minimum core temperature, $<34.5{ }^{\circ} \mathrm{C}$ ) and recipient-site infections (Hill et al., 2015). Intraoperative hypothermia (minimum core temperature, $<35.0^{\circ} \mathrm{C}$ ) also is correlated with overall perioperative complications (Sumer et al., 2009). Maintenance of normothermia may be difficult with a large areas exposed for prolonged periods during surgery, predisposing patients to hypothermia. In addition, anaesthesia changes the thermoregulatory mechanisms. Central and peripheral temperature must be monitored and the ideal difference between them should be less than $2{ }^{\circ} \mathrm{C}$ (Hagau and Longrois, 2009). If preventative measures are not in place, hypothermia may occur in as many as 50 to 90 per cent of surgical patients (Young and Watson, 2006). Since the majority of studies found that hypothermia is associated with perioperative complications, it is recommended to maintain ambient room temperature at approximately $24{ }^{\circ} \mathrm{C}$ before patients are in the operating room, and other preventative efforts should be made to avoid hypothermia (Gardiner and Nanchahal, 2010).

\section{CONCLUSIONS}

More attention should be focused on timely preoperative evaluation of patient-dependent risk factors, which can influence anaesthesiological and surgical tactics during and after microvascular free flap surgery. Perioperative anaesthesiological management strategy continues to be controversial therefore it should be performed based on thrombotic risk assessment and patient individual needs, thus improving flap survival rates and surgical outcome.

\section{REFERENCES}

Adams, J., Charlton, P. (2003). Anaesthesia for microvascular free tissue transfer. Brit. J. Anaesth. CEPD Rev., 3 (2), 33-37. 
Al-Dam, A., Zrnc, T. A., Hanken, H., Riecke, B., Eichhorn, W., Nourwali, I., Gröbe, A. (2014). Outcome of microvascular free flaps in a high-volume training centre. J. Cranio-Maxillo-Facial Surg., 42 (7), 1178-1183.

Annecke, T., Chappell, D., Chen, C., Jacob, M., Welsch, U., Sommerhoff, C. P., Becker, B. F. (2010). Sevoflurane preserves the endothelial glycocalyx against ischaemia-reperfusion injury. Brit. J. Anaesth., 104 (4), 414-421.

Arellano, R., Gan, B. S., Salpeter, M. J., Yeo, E., McCluskey, S., Pinto, R., Lampe, H. (2005). A triple-blinded randomized trial comparing the hemostatic effects of large-dose $10 \%$ hydroxyethyl starch $264 / 0.45$ versus $5 \%$ albumin during major reconstructive surgery. Anesth. Analg., 100 (6), 1846-1853.

Ashjian, P., Chen, C. M., Pusic, A., Disa, J. J., Cordeiro, P. G., Mehrara, B. J. (2007). The effect of postoperative anticoagulation on microvascular thrombosis. Ann. Plastic Surg., 59 (1), 36-39.

Booi, D. I. (2011). Perioperative fluid overload increases anastomosis thrombosis in the free TRAM flap used for breast reconstruction. Eur. J. Plastic Surg., 34 (2), 81-86.

Bozkurt, M., Kulahci, Y., Zor, F., Sen, H., Acikel, C. H., Deveci, M., Sengezer, M. (2010). Comparison of the effects of inhalation, epidural, spinal, and combined anesthesia techniques on rat cremaster muscle flap microcirculation. Microsurgery, 30 (1), 55-60.

Brands, M. T., van den Bosch, S. C., Dieleman, F. J., Bergé, S. J., Merkx, M. A. W. (2010). Prevention of thrombosis after microvascular tissue transfer in the head and neck. A review of the literature and the state of affairs in Dutch Head and Neck Cancer Centers. Int. J. Oral Maxillofacial Surg., 39 (2), 101-106

Brinkman, J. N., Derks, L. H., Klimek, M., Mureau, M. A. M. (2013). Perioperative fluid management and use of vasoactive and antithrombotic agents in free flap surgery: A literature review and clinical recommendations. J. Reconstr. Microsurg., 29 (6), 357-66.

Bruegger, D., Bauer, a, Finsterer, U., Bernasconi, P., Kreimeier, U., Christ, F. (2002). Microvascular changes during anesthesia: Sevoflurane compared with propofol. Acta Anaesthesiol. Scand., 46 (5), 481-487.

Cayci, C., Cinar, C., Yucel, O. a, Tekinay, T., Ascherman, J. A. (2010). The effect of epidural anesthesia on muscle flap tolerance to venous ischemia. Plastic Reconstr. Surg., 125 (1), 89-98.

Chang, D. W. (2006). The effect of smoking on flap and donor-site complications in pedicled TRAM breast reconstruction. Breast Dis., 17, 295-296.

Chang, E. I., Carlsen, B. T., Festekjian, J. H., Da Lio, A. L., Crisera, C. A. (2013). Salvage rates of compromised free flap breast reconstruction after recurrent thrombosis. Ann. Plastic Surg., 71 (1), 68-71.

Chappell, D., Jacob, M., Hofmann-Kiefer, K., Conzen, P., Rehm, M. (2008). A rational approach to perioperative fluid management. Anesthesiology, 109 (4), 723-740.

Chen, C. M., Ashjian, P., Disa, J. J., Cordeiro, P. G., Pusic, A. L., Mehrara, B. J. (2008). Is the use of intraoperative heparin safe? Plastic Reconstr. Surg., 121 (3), 49e-53e.

Chen, C., Nguyen, M.-D., Bar-Meir, E., Hess, P. a, Lin, S., Tobias, A. M., Lee, B. T. (2010). Effects of vasopressor administration on the outcomes of microsurgical breast reconstruction. Ann. Plastic Surg., 65 (1), 28-31.

Chien, W., Varvares, M. A., Hadlock, T., Cheney, M., Deschler, D. G. (2005). Effects of aspirin and low-dose heparin in head and neck reconstruction using microvascular free flaps. The Laryngoscope, 115 (6), 973-976.

Clark, J. R. J., McCluskey, S. A. S., Hall, F., Lipa, J., Neligan, P., Brown, D., Gilbert, R. (2007). Predictors of morbidity following free flap reconstruction for cancer of the head and neck. Head Neck, 29 (December), 1090-1101.

Coskunfirat, O. K., Chen, H., Spanio, S., Tang, Y. (2005). The safety of microvascular free tissue transfer in the elderly population. Plastic Reconstr. Surg., 115 (3), 771-775.

Davison, S. P., Kessler, C. M., Al-Attar, A. (2009). Microvascular free flap failure caused by unrecognized hypercoagulability. Plastic Reconstr. Surg., 124 (2), 490-495.
De Stefano, V., Martinelli, I., Mannucci, P. M., Paciaroni, K., Chiusolo, P., Casorelli, I., Leone, G. (1999). The risk of recurrent deep venous thrombosis among heterozygous carriers of both factor V Leiden and the G20210A prothrombin mutation. New Engl. J. Med., 341 (11), 801-806.

Disa, J. J., Polvora, V. P., Pusic, A. L., Singh, B., Cordeiro, P. G. (2003). Dextran-related complications in head and neck microsurgery: Do the benefits outweigh the risks? A prospective randomized analysis. Plastic Reconstr. Surg., 112 (6), 1534-1539.

Eley, K. A, Young, J. D., Watt-Smith, S. R. (2012). Epinephrine, norepinephrine, dobutamine, and dopexamine effects on free flap skin blood flow. Plastic Reconstr. Surg., 130 (3), 564-570.

Eley, K. A., Young, J. D., Watt-Smith, S. R. (2013). Power spectral analysis of the effects of epinephrine, norepinephrine, dobutamine and dopexamine on microcirculation following free tissue transfer. Microsurgery, 33 (4), 275-281.

Erni, D., Banic, a, Signer, C., Sigurdsson, G. H. (1999). Effects of epidural anaesthesia on microcirculatory blood flow in free flaps in patients under general anaesthesia. Eur. J. Anaesthes., 16 (10), 692-698.

Fischer, J. P., Nelson, J. a, Sieber, B., Stransky, C., Kovach, S. J., Serletti, J. M., Wu, L. C. (2014). Transfusions in autologous breast reconstructions: An analysis of risk factors, complications, and cost. Ann. Plastic Surg., 72 (5), 566-571.

Fischer, J. P., Wink, J. D., Nelson, J. A., Cleveland, E., Grover, R., Wu, L. C., Kovach, S. J. (2013). A retrospective review of outcomes and flap selection in free tissue transfers for complex lower extremity reconstruction. $J$. Reconstr. Microsurg., 29 (6), 407-416.

Gardiner, M. D., Nanchahal, J. (2010). Strategies to ensure success of microvascular free tissue transfer. J. Plastic Reconstr. Aesthetic Surg., 63 (9), e665-73.

Gerressen, M., Pastaschek, C. I., Riediger, D., Hilgers, R.-D., Hölzle, F., Noroozi, N., Ghassemi, A. (2013). Microsurgical free flap reconstructions of head and neck region in 406 cases: A 13-year experience. J. Oral Maxillofacial Surg., 71 (3), 628-635.

Godina, M. (1979). Preferential use of end-to-side arterial anastomoses in free flap transfers. Plastic Reconstr. Surg., 64 (5), 673-682.

Hagau, N., Longrois, D. (2009). Anesthesia for free vascularized tissue transfer. Microsurgery, 29 (2), 161-167.

Handschel, J., Burghardt, S., Naujoks, C., Kübler, N. R., Giers, G. (2013). Parameters predicting complications in flap surgery. Oral Surg. Oral Med. Oral Pathol. Oral Radiol., 115 (5), 589-594.

Hill, J. B., Patel, A., Del Corral, G. A, Sexton, K. W., Ehrenfeld, J. M., Guillamondegui, O. D., Shack, R. B. (2012). Preoperative anemia predicts thrombosis and free flap failure in microvascular reconstruction. Ann. Plastic Surg., 69 (4), 364-367.

Hill, J. B., Sexton, K. W., Bartlett, E. L., Papillion, P. W., Del Corral, G. A., Patel, A., Shack, R. B. (2015). The clinical role of intraoperative core temperature in free tissue transfer. Ann. Plastic Surg., 75 (6), 620-624.

Höijer, P., Olsson, E. (2006). Elevated coagulation factor VIII, postoperative thrombosis and flap failure in late breast reconstruction with a free TRAM flap: A case report. J. Plastic Reconstr. Aesthetic Surg., 59 (1), 102-104.

Kakarala, K., Emerick, K. S., Lin, D. T., Rocco, J. W., Deschler, D. G. (2012). Free flap reconstruction in 1999 and 2009: Changing case characteristics and outcomes. The Laryngoscope, 122 (10), 2160-2163.

Kao, H. K., Chang, K. P., Ching, W. C., Tsao, C. K., Cheng, M. H., Wei, F. C. (2010). Postoperative morbidity and mortality of head and neck cancers in patients with liver cirrhosis undergoing surgical resection followed by microsurgical free tissue transfer. Ann. Surg. Oncol., 17 (1534-4681 (Electronic)), 536-543.

Karakida, K., Aoki, T., Ota, Y., Yamazaki, H., Otsuru, M., Takahashi, M., Miyasaka, M. (2010). Analysis of risk factors for surgical-site infections in 276 oral cancer surgeries with microvascular free-flap reconstructions at a single university hospital. J. Inf. Chemother., 16 (5), 334-339. 
Kelly, D. A, Reynolds, M., Crantford, C., Pestana, I. A. (2014). Impact of intraoperative vasopressor use in free tissue transfer for head, neck, and extremity reconstruction. Ann. Plastic Surg., 72 (6), S135-138.

Khansa, I., Colakoglu, S., Tomich, D. C., Nguyen, M.-D., Lee, B. T. (2011). Factor V Leiden associated with flap loss in microsurgical breast reconstruction. Microsurgery, 31 (5), 409-412.

Khouri, R. K., Cooley, B. C., Kunselman, A. R., Landis, J. R., Yeramian, P., Ingram, D., Wallemark, C. (1998). A prospective study of microvascular free-flap surgery and outcome. Plastic Reconstr. Surg., 102 (3), 711-721.

Kim, B. D., Ver Halen, J. P., Mlodinow, A. S., Kim, J. Y. S. (2014). Intraoperative transfusion of packed red blood cells in microvascular free tissue transfer patients: Assessment of 30-day morbidity using the NSQIP dataset. J. Reconstr. Microsurg., 30 (2), 103-114.

Kitchens, C. (2008). Concept of hypercoagulability: A review of its development, clinical application, and recent progress. Seminars Thromb. Hemostasis, 11 (03), 293-315.

Kolbenschlag, J., Daigeler, A., Lauer, S., Wittenberg, G., Fischer, S., Kapalschinski, N., Goertz, O. (2014). Can rotational thromboelastometry predict thrombotic complications in reconstructive microsurgery? Microsurgery, 34 (4), 253-260.

Kozek-Langenecker, S. A, Afshari, A., Albaladejo, P., Santullano, C. A. A., De Robertis, E., Filipescu, D. C., Wyffels, P. (2013). Management of severe perioperative bleeding: Guidelines from the European Society of Anaesthesiology. Eur. J. Anaesthesiol., 30 (6), 270-382.

Kuri, M., Nakagawa, M., Tanaka, H., Hasuo, S., Kishi, Y. (2005). Determination of the duration of preoperative smoking cessation to improve wound healing after head and neck surgery. Anesthesiology, 102 (5), 892-896.

Kurt, E., Ozturk, S., Isik, S., Zor, F. (2005). Continuous brachial plexus blockade for digital replantations and toe-to-hand transfers. Ann. Plastic Surg., 54 (1), 24-27.

Labow, B. I., Greene, A. K., Upton, J. (2007). Homocystinuria: An unrecognized cause of microvascular failure. Plastic Reconstr. Surg., 120 (1), $6 \mathrm{e}-12 \mathrm{e}$.

Lee, K. T., Jeon, B.-J., Lim, S.-Y., Pyon, J.-K., Bang, S.-I., Oh, K.-S., Mun, G.-H. (2012). The effects of ketorolac on microvascular thrombosis in lower extremity reconstruction. Plastic Reconstr. Surg., 129 (6), 1322-1327.

Lee, Y. K., Park, K. Y., Koo, Y. T., Baek, R. M., Heo, C. Y., Eun, S. C., Kim, B. K. (2014). Analysis of multiple risk factors affecting the result of free flap transfer for necrotising soft tissue defects of the lower extremities in patients with type 2 diabetes mellitus. J. Plastic Reconstr. Aesthetic Surg., 67 (5), 624-628.

Lighthall, J. G., Cain, R., Ghanem, T. A., Wax, M. K. (2013). Effect of postoperative aspirin on outcomes in microvascular free tissue transfer surgery. Otolaryngol. Head Neck Surg., 148 (1), 40-46.

Liu, S.-A., Wong, Y.-K., Poon, C.-K., Wang, C.-C., Wang, C.-P., Tung, K.-C. (2007). Risk factors for wound infection after surgery in primary oral cavity cancer patients. The Laryngoscope, 117 (1), 166-171.

Liu, Y.-J., Hirsch, B. P., Shah, A. A, Reid, M. A, Thomson, J. G. (2011). Mild intraoperative hypothermia reduces free tissue transfer thrombosis. $J$. Reconstr. Microsurg., 27 (2), 121-126.

Louer, C. R., Chang, J. B., Hollenbeck, S. T., Zenn, M. R. (2013). Autologous blood use for free flap breast reconstruction: A comparative evaluation of a preoperative blood donation program. Ann. Plast.Surg., 70 (2), 158-161

Lucchinetti, E., Ambrosio, S., Aguirre, J., Herrmann, P., Härter, L., Keel, M., Zaugg, M. (2007). Sevoflurane inhalation at sedative concentrations provides endothelial protection against ischemia-reperfusion injury in humans. Anesthesiology, 106 (2), 262-268.

Masoomi, H., Clark, E. G., Paydar, K. Z., Evans, G. R. D., Nguyen, A., Kobayashi, M. R., Wirth, G. A. (2014). Predictive risk factors of free flap thrombosis in breast reconstruction surgery. Microsurgery, 34 (8), 589-94.

Nahabedian, M. Y. Free Tissue Transfer Flaps: Definition, Indications, Preoperative Considerations. (n.d.). Available at: http://emedicine.medscape.com/article/1284841-overview\#showall (accessed 14 November 2015).

McLean, D. H., Buncke, H. J. (1972). Autotransplant of omentum to a large scalp defect, with microsurgical revascularization. Plastic Reconstr. Surg., 49 (3), 268-274.

Mlodinow, A. S., Ver Halen, J. P., Rambachan, A., Gaido, J., Kim, J. Y. S. (2013). Anemia is not a predictor of free flap failure: A review of NSQIP data. Microsurgery, 33 (6), 432-438.

Monroe, M. M., Cannady, S. B., Ghanem, T. A, Swide, C. E., Wax, M. K. (2011). Safety of vasopressor use in head and neck microvascular reconstruction: A prospective observational study. Otolaryngol. Head Neck Surg., 144 (6), 877-882.

Motakef, S., Mountziaris, P. M., Ismail, I. K., Agag, R. L., Patel, A. (2015). Emerging paradigms in perioperative management for microsurgical freet transfer. Plastic Reconstr. Surg., 135 (1), 290-299.

Monroe, M. M., McClelland, J., Swide, C., Wax, M. K. (2010). Vasopressor use in free tissue transfer surgery. Otolaryngol. Head Neck Surg., 142 (2), $169-173$.

Müller, M. C., Meijers, J. C. M., Vroom, M. B., Juffermans, N. P. (2014). Utility of thromboelastography and/or thromboelastometry in adults with sepsis: A systematic review. Crit. Care, 18 (1), R30.

Oh, T. S., Lee, H. S., Hong, J. P. (2013). Diabetic foot reconstruction using free flaps increases 5-year-survival rate. J. Plastic Reconstr. Aesthetic Surg., 66 (2), 243-250.

Olsson, E., Svartling, N., Asko-Seljavaara, S., Lassila, R. (2001). Activation of coagulation and fibrinolysis during reconstructive microsurgery in patients with cancer. Microsurgery, 21 (5), 208-213.

Ozkan, O., Ozgentas, H. E., Islamoglu, K., Boztug, N., Bigat, Z., Dikici, M. B. (2005). Experiences with microsurgical tissue transfers in elderly patients. Microsurgery, 25 (5), 390-395.

Patel, R. S., McCluskey, S. A., Goldstein, D. P., Minkovich, L., Irish, J. C., Brown, D. H., Gilbert, R. W. (2010). Clinicopathologic and therapeutic risk factors for perioperative complications and prolonged hospital stay in free flap reconstruction of the head and neck. Head Neck, 32 (10), 1345-1353.

Pohlenz, P., Blessmann, M., Heiland, M., Blake, F., Schmelzle, R., Li, L. (2007). Postoperative complications in 202 cases of microvascular head and neck reconstruction. J. Cranio-Maxillofacial Surg., 35 (6-7), 311-315.

Quinlan, J., Lodi, O. (2009). Anaesthesia for reconstructive surgery. Anaesthesia Intensive Care Med., 10 (1), 26-31.

Riva, F. M. G., Chen, Y., Tan, N., Lin, P., Tsai, Y., Chang, H., Kuo, Y. (2012). The outcome of prostaglandin-E1 and dextran-40 compared to no antithrombotic therapy in head and neck free tissue transfer: analysis of 1,351 cases in a single center. Microsurgery, 32 (5), 339-343.

Rosenberg, a. J. W. P., Van Cann, E. M., van der Bilt, a., Koole, R., van Es, R. J. J. (2009). A prospective study on prognostic factors for free-flap reconstructions of head and neck defects. Int. J. Oral Maxillofacial Surg., 38 (6), 666-670.

Rosendaal, F. R. (1999). Venous thrombosis: A multicausal disease. Lancet, 353 (9159), 1167-1173.

Scalia, R., Gong, Y., Berzins, B., Zhao, L. J., Sharma, K. (2007). Hyperglycemia is a major determinant of albumin permeability in diabetic microcirculation: The role of mu-calpain. Diabetes, 56 (7), 1842-1849.

Sezgin, B., Ayhan, S., Tuncer, S., Sencan, A., Aral, M. (2012). Hypercoagulability in microvascular breast reconstruction: An algorithmic approach for an underestimated situation. J. Reconstr. Microsurg., 28 (8), $515-520$.

Shetty, P. S., Boyce, H., Chisholm, D. (2009). Anaesthesia for onco-plastic reconstructive surgery. Curr. Anaesthesia Crit. Care, 20 (1), 18-21.

Shum, J., Markiewicz, M. R., Park, E., Bui, T., Lubek, J., Bryan Bell, R., Dierks, E. J. (2014). Low prealbumin level is a risk factor for microvascular free flap failure. J. Oral Maxillofacial Surg., 72 (1), 169-177. 
Sigurdsson, G. H., Thomson, D. (1995). Anaesthesia and microvascular surgery: Clinical practice and research. Eur. J. Anaesthesiol., 12 (2), 101-122.

Stepanovs J., Ozolina A., Mamaja B. (2015). Preoperative detection of thrombogenic factors in reconstructive microvascular surgery. Eur. J. Anaesthesiol., 32, e-Supplement 53, 8AP4-6, 258 p. Available at: https://www.esahq.org/ /media/ESA/Files/Downloads/Resources-Abstracts-Euroanaesthesia2015/Euroanaesthesia\%202015\%20A bstract\%20Book.ashx (accessed 15.06.2015).

Su, H.-H., Lui, P.-W., Yu, C.-L., Liew, C.-S., Lin, C.-H., Lin, Y.-T., Yang, M.-W. (2005). The effects of continuous axillary brachial plexus block with ropivacaine infusion on skin temperature and survival of crushed fingers after microsurgical replantation. Chang Gung Med. J., 28 (8), 567-574.

Sumer, B. D., Myers, L. L., Leach, J., Truelson, J. M. (2009). Correlation between intraoperative hypothermia and perioperative morbidity in patients with head and neck cancer. Arch. Otolaryngol. Head Neck Surg., 135 (7), 682-686.

Szakmany, T., Dodd, M., Dempsey, G. a, Lowe, D., Brown, J. S., Vaughan, E. D., Rogers, S. N. (2006). The influence of allogenic blood transfusion in patients having free-flap primary surgery for oral and oropharyngeal squamous cell carcinoma. Brit. J. Cancer, 94 (5), 647-653.

Thomson, J. G., Mine, R., Shah, A., Palesty, J. A., Yaghjyan, G., Ahmed, S., Chao, R. P. (2009). The effect of core temperature on the success of free tissue transfer. J. Reconstr. Microsurg., 25 (7), 411-416.

Vamvakas, E. C., Blajchman, M. A. (2007). Transfusion-related immunomodulation (TRIM): An update. Blood Rev., 21 (6), 327-348.

Vandenbroucke, J. P., Rosing, J., Bloemenkamp, K. W., Middeldorp, S., Helmerhorst, F. M., Bouma, B. N., Rosendaal, F. R. (2001). Oral contraceptives and the risk of venous thrombosis. New Engl. J. Med., 344, 1527-1535.

Wang, T. Y., Serletti, J. M., Cuker, A., McGrath, J., Low, D. W., Kovach, S. J., Wu, L. C. (2012). Free tissue transfer in the hypercoagulable patient: A review of 58 flaps. Plastic Reconstr. Surg., 129 (2), 443-453.
Wei, F., Jain, V., Celik, N., Chen, H., Chuang, D. C.-C., Lin, C. (2002). Have we found an ideal soft-tissue flap? An experience with 672 anterolateral thigh flaps. Plastic Reconstr. Surg., 109 (7), 2219-2226; discussion 2227-2230.

Wettstein, R., Schürch, R., Banic, A., Erni, D., Harder, Y. (2008). Review of 197 consecutive free flap reconstructions in the lower extremity. J. Plastic Reconstr. Aesthetic Surg., 61 (7), 772-776.

Wikner, J., Beck-Broichsitter, B. E., Schlesinger, S., Schön, G., Heiland, M., Assaf, A. T., Heckel, K. (2015). Thromboelastometry: A contribution to perioperative free-flap management. J. Cranio-Maxillo-Facial Surg., 43 (7), 1065-1071.

Wolff, K. D., Holzle, F., Wysluch, A., Mucke, T., Kesting, M. (2008). Incidence and time of intraoperative vascular complications in head and neck microsurgery. Microsurgery, 28 (3), 143-146.

Wong, A. K., Joanna Nguyen, T., Peric, M., Shahabi, A., Vidar, E. N., Hwang, B. H., Urata, M. M. (2015). Analysis of risk factors associated with microvascular free flap failure using a multi-institutional database. Microsurgery, 35 (1), 6-12.

Yoshimoto, S., Kawabata, K., Mitani, H. (2010). Factors involved in free flap thrombosis after reconstructive surgery for head and neck cancer. Auris Nasus Larynx, 37 (2), 212-216.

Young, V. L., Watson, M. E. (2006). Prevention of perioperative hypothermia in plastic surgery. Aesth. Surg. J., 26 (5), 551-571.

Yu, P., Chang, D. W., Miller, M. J., Reece, G., Robb, G. L. (2009). Analysis of 49 cases of flap compromise in 1310 free flaps for head and neck reconstruction. Head Neck, 31 (1), 45-51.

Zellans, E., Ozolina, A., Lace, I., Strike, E., Daukste, M., Lacis, R. (2014). Impact of preoperative anaemia on outcome in elective on-pump cardiac surgery. Acta Chir. Latv., 14 (2), 3-7.

Zhong, T., Neinstein, R., Massey, C., McCluskey, S., Lipa, J., Neligan, P., Hofer, S. O. P. (2011). Intravenous fluid infusion rate in microsurgical breast reconstruction: Important lessons learned from 354 free flaps. Plastic Reconstr. Surg., 128 (6), 1153-1160.

Received 9 December 2015

\section{BRĪVO LĒVERU TROMBOŽU RISKU IETEKMĒJOŠIE FAKTORI MIKROVASKULĀRAJĀ KIRURG̣IJĀ}

Mikrovaskulārā brīvo lēveru ķirurğija pēdējās dekādes laikā ir kḷuvusi par nozīmīgu rekonstruktīvās ķirurğijas daḷu, ḷaujot slēgt defektus dažāōos audos, atjaunojot normālu orgānu funkciju. Neraugoties uz ievērojamo progresu mikrovaskulārajā kirurğijāa, kas rezultējas ar pārvietoto audu augstu izdzīvošanas procentu, lēvera kājiņas asinsvadu trombozes risks joprojām paliek nozīmīga problēma. Literatūras pārskatā analizētas 108 publikācijas no Pubmed un Science Direct datu bāzēm par 2005.-2015. gadu periodu; izvērtēta no pacienta atkarīgo riska faktoru un dažādu perioperatīvās aprūpes aspektu ietekme uz brīvā lēvera asinsvadu trombozi. Identificēta no pacienta atkarīgo riska faktoru - hiperkoagulācijas, vecuma un blakusslimību — ietekme. Mūsdienās rotācijas trombelastometrija ḷauj agrīni atklāt hiperkoagulāciju, nozīmīgi mainot turpmāko pacienta ārstēšanas stratēégiju. Pirmsoperācijas periodā ir būtiska arī ar kirurǵiju saistîto lēvera trombozi veicinošo faktoru identifikācija. Anestēzijas un perioperatīvās analgēzijas izvēele, dažādu šḳidrumu veidu un daudzumu, asins produktu, vazoaktīvo medikamentu nozīmēšana, temperatūras kontrole ir ne mazāk svarīgi aspekti ārstēšanas taktikas izvēlē perioperatīvajā periodā. Pirmsoperācijas novērtēšanā vairāk uzmanības vajadzētu pievērst savlaicīgai no pacienta atkarīgo faktoru izvērtēšanai, kas var ietekmēt anestezioloǵisko un kirurǵisko taktiku mikrovaskulārajā brīvo lēveru kirurǵijā. Perioperatīvā anestezioloğiskā aprūpes stratēǵija joprojām ir pretrunīga, tai jātiek īstenotai, balstoties uz trombožu risku izvērtěšanu un pacientu individuālajām prasībām, uzlabojot lēvera izdzīvošanu un kịurǵisko rezultātu. 